\title{
Holocene tectonic uplift deduced from elevated shorelines, eastern Coastal Range of Taiwan
}

\author{
P.M. Liew ${ }^{\text {a }}$, P.A. Pirazzoli ${ }^{b}$, M.L. Hsieh ${ }^{a}$, M. Arnold ${ }^{c}$, J.P. Barusseau $^{\text {d }}$, M. Fontugne ${ }^{c}$ \\ and P. Giresse ${ }^{\mathrm{d}}$ \\ a Department of Geology, National Taiwan University, 245 Choushan Road, Taipei, Taiwan, ROC \\ ${ }^{b}$ CNRS-URA141, Laboratoire de Géographie Physique, 1 Place Aristide Briand, 92190 Meudon-Bellevue, France \\ ${ }^{c}$ CNRS-CEA, Centre des Faibles Radioactivités, Avenue de la Terrasse, 91198 Gif-sur-Yvette, France \\ ${ }^{d}$ Laboratoire de Recherches de Sédimentologie Marine, Université de Perpignan, 66860 Perpignan, France
}

(Received September 8, 1992; revised version accepted January 11, 1993)

\begin{abstract}
This paper is concerned with the tectonic trends that can be deduced from the Holocene raised shorelines between Ch'eng-kung and Hsin-she, along a $65-\mathrm{km}$ long coastal sector in the eastern Coastal Range of Taiwan. Sequences of up to eight superimposed shorelines have been identified in a single section. Twelve new radiocarbon dates (six of which were obtained by accelerator mass spectrometry) of in-situ marine samples (up to $40 \mathrm{~m}$ in altitude) have confirmed a Holocene age. However, it is difficult to define clearly the upper marine boundary in the highest Holocene coastal terraces, which have been uplifted to $65-70 \mathrm{~m}$, but have been capped by, and often also interfingered with, alluvial deposits. High uplift rates, ranging from $2.5-3.0$ to over $8 \mathrm{~mm} / \mathrm{yr}$, have been inferred along the coast, providing evidence of differential uplift. In some cases uplift movements appear to have occurred by steps, probably spasmodically. Recurrence periods of fast uplifts seem to be of the order of at most $1000 \mathrm{yr}$. This means that a new spasmodic movement may be imminent, because the last displacement (4-6 m) has been dated about 1000 yг BP.
\end{abstract}

\section{Introduction}

The eastern Coastal Range of Taiwan is an accreted prism of the Luzon arc, belonging to the Philippine Sea plate, which collided with the Eurasian plate margin (Angelier et al., 1986; Angelier, 1990) (Fig. 1). The main geological units of the eastern Coastal Range are the raised arc itself and the fore-arc or intra-arc basin sequences. Faults, mainly oriented towards the northeast, are the first-order structures of this accreted terrain. As shown by paleontologic (Chi et al., 1985; Huang and Lin, 1991), volcanologic (Yang et al., 1992), and paleomagnetic studies (Yang et al., 1983; Lec, 1989), intensive collision has occurred since the late Pliocene and has propagated southwards. Recent tectonic activity of the eastern Coastal Range is indicated by the high level of seismicity and by the rapid uplift rates revealed by geodetic ( $\mathrm{Liu}$ and $\mathrm{Yu}, 1990$ ) and geomorphological data (Liew et al., 1990), espe- cially in the middle and southern parts of the coastal area.

The raised marine terraces of the east coast of Taiwan have been studied by Lin (1969), who ascribed six surfaces of marine abrasion or of raised coral reefs to the Holocene, the uppermost of which (Paishoulien Surface) is reported at altitudes varying from 40 to $60-80 \mathrm{~m}$. The first radiometric datings from this area (Hsu et al., 1973; see Pirazzoli, 1978, for an early regional compilation) confirmed the Holocene age of certain raised coral reef formations, implying relatively high uplift rates. The geomorphology of the marine terraces between Hua-lien * and T'ai-tung was studied subsequently by Lai (1986), Shih et al. (1988), Liew et al. (1990) and Hsieh (1990). Lai (1986) described the marine tcrraccs of the middle part of the coast; Shih et al. (1988) di-

\footnotetext{
* For Chinese names, English transcription has been used.
} 
vided the terraces along the coast into three main surfaces. Liew et al. (1990) confirmed, on the basis of some radiometric ages, that the highest well-preserved surface belongs to the Holocene. Owing to the scarcity of dating material from the formcr shorelines, an estimation of average uplift rates in the coastal zone was attempted in a previous paper (Liew et al., 1990) using a sea-level curve from eastern China as a reference. By accumulating more age data, it now has become possible to bring into evidence that differential uplift rates occur in certain parts of the coastal zone, implying local changes in dynamic geomorphological processes. In this paper we present new data from the middle and southern parts of the coast, covering about $65 \mathrm{~km}$ between Ch'engkung and Hsin-she, where the mean spring tidal range is about $1.45 \mathrm{~m}$.

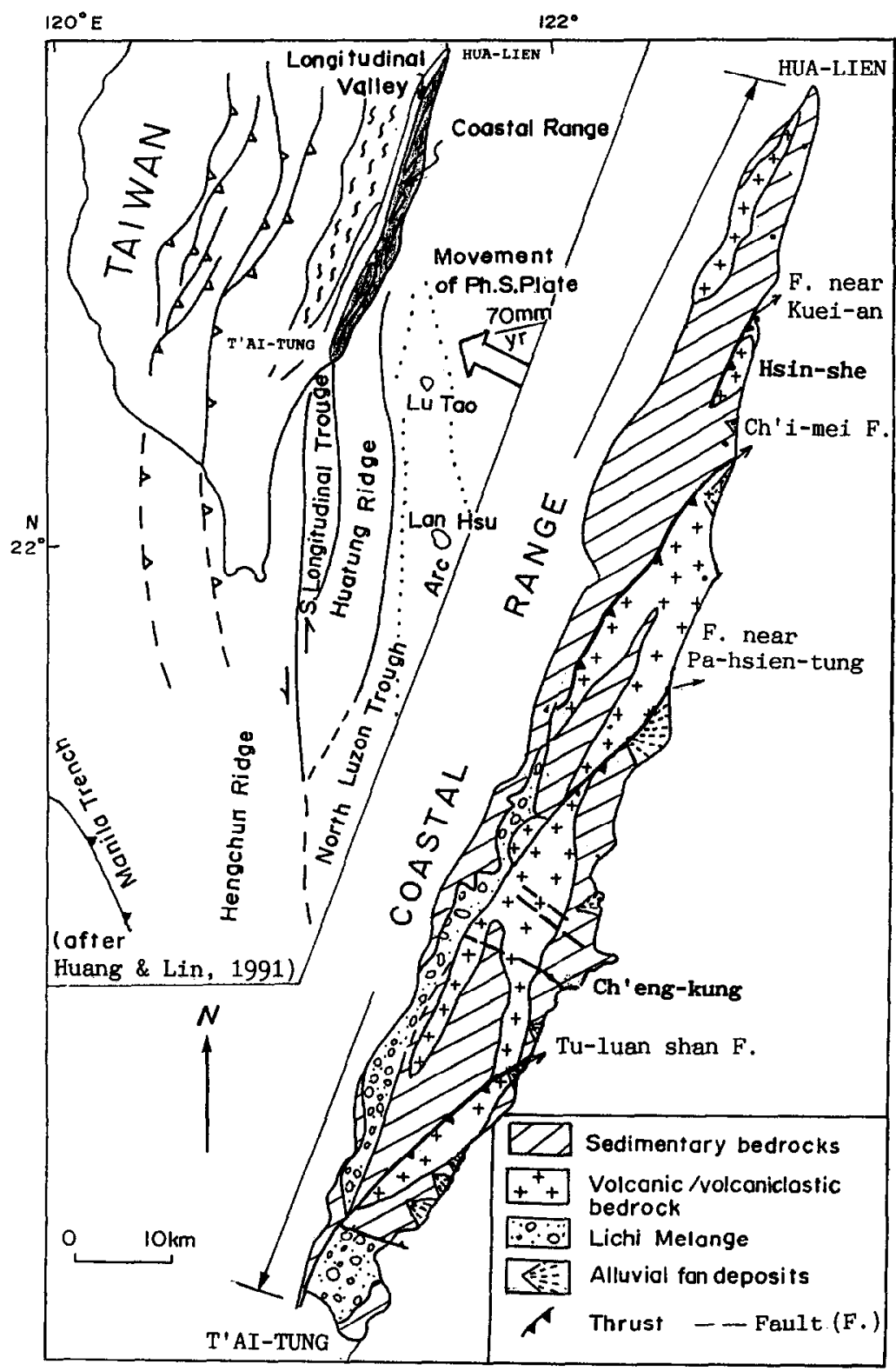

Fig. 1. Location of the study area. 


\section{Methods and materials}

\section{Determination of former sea-level positions}

There are many ways of recognizing the position of a former sea-level stand, e.g., using bioconstructions, marine deposits, erosional features, etc. (Van de Plassche, 1986). Stepped erosional features (superimposed notches and/or benches) are characteristic of tectonic coasts affected by repeated vertical movements. On the east coast of Taiwan, raised stepped sequences can be observed in various places. Near Shih-yüsan (Fig. 2, loc. 4), five superimposed notches are visible in a single section between 25 and $37 \mathrm{~m}$ above present sea level (see below, Fig. 5); near Ching-p'u, between localities 9 and 10, at least eight stepped shorelines can be distinguished up to about $+38 \mathrm{~m}$.

Radiometric dating of biogenic material is often of great help in estimating the age of former sea levels. Stony corals develop below the low-tide level, reaching depths that may vary with each species considered and with water transparency but generally do not exceed $15-20 \mathrm{~m}$ (although some species can live at depths of $50-100 \mathrm{~m}$ below the surface). Accordingly, it has been assumed (Table 1, PaleoMSL elevations) that coral samples collected in growth position indicate minimum former sea-level elevations. In the same way borer shells, which can live at any depth, generally provide minimum elevation estimates when collected in their hole with their valves still joined. In addition, the upper limit of elevated borer shells, when it is clearly marked, can provide very reliable information on the former sealevel position. The preservation of shells inside fossil burrows is an indication of very rapid (probably instantaneous) change in sea level, because if elevation was gradual (centimetres or even decimetres per year) these remains would have been damaged and destroyed within a few years

(a)

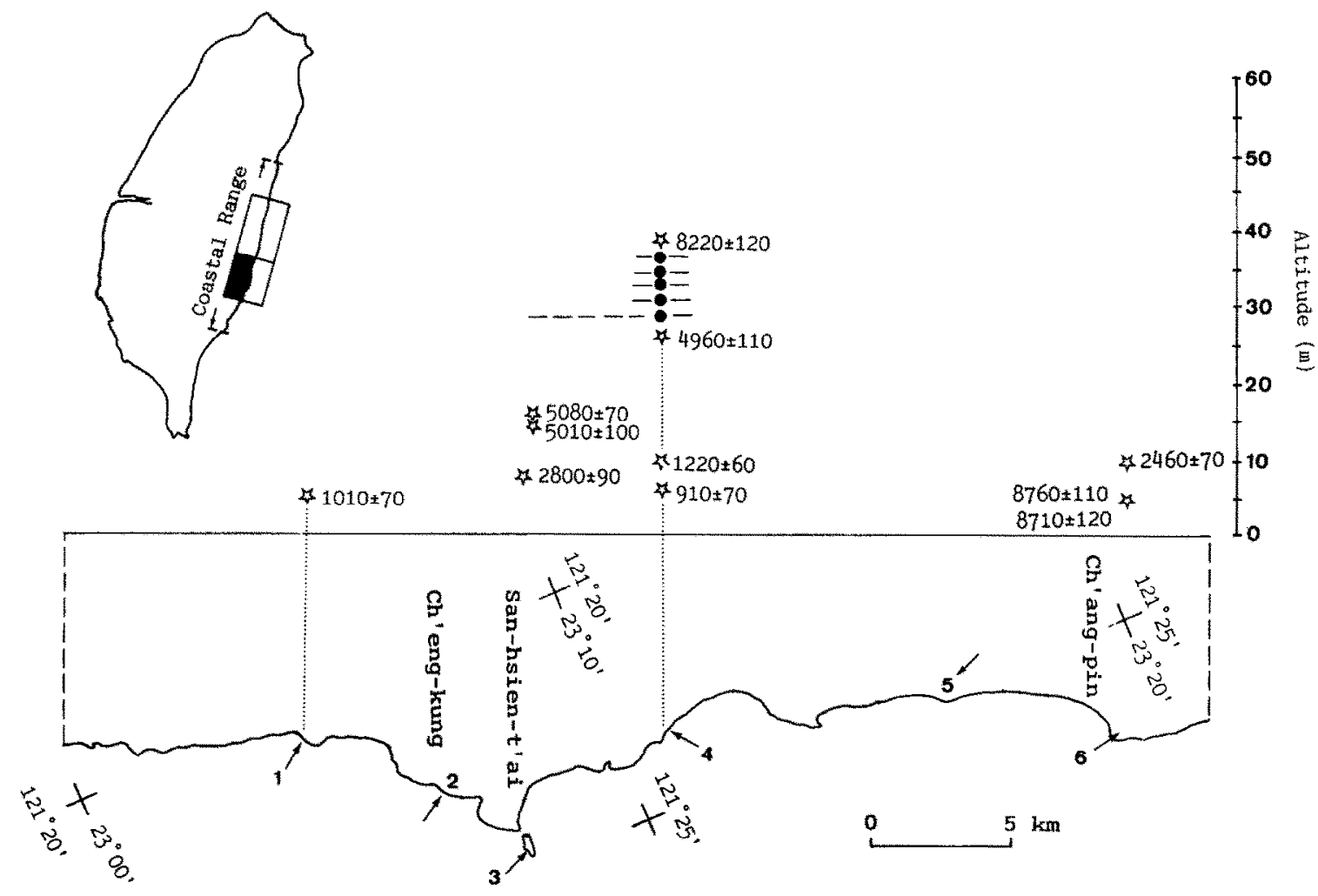

Fig. 2. Location of new dated samples (stars) and measured shorelines (dots) (a) from Ch'eng-kung to Ch'ang-pin, (b) from Ch'ang-pin to Feng-pin. Open circles = major sea caves, possibly Pleistocene in age. Lateral correlation is attempted with dashed lines. 
by bioerosion (Stiros et al., 1992). On the other hand, as freshwater peat usually forms above sea level, peat samples collected in situ can only indicate maximum former sea-level elevations. In the same way driftwood, which is usually deposited in the upper beach, also indicates maximum former sea levels.

Intertidal encrusting shells (oysters, barnacles) collected in growth position are obviously very precise sea-level indicators. Finally, beach or nearshore deposits, consisting of possibly reworked material, should be interpreted cautiously because they may have been deposited at various heights in relation to the former sea level and their apparent age may have been modified by the inclusion of material eroded from older deposits.

\section{Radiometric analyses}

Radiocarbon measurements have been performed by $\mathrm{CO}_{2}$ B-counting on the large coral samples, at the Centre des Faibles Radioactivités, and, for the small shcll fragments, by accelerator mass spectrometry (AMS) at the Tandetron facility of Gif-sur-Yvette where ${ }^{14} \mathrm{C}$ measurements of samples containing a few hundreds microgrammes of carbon are performed routinely (Arnold et al., 1987, 1989).

For B-counting samples, X-ray diffraction analysis shows that all samples were pure aragonite (except the calcitic algal sample: Gif-8646) which probably excludes recrystallization processes. Samples were cleaned mechanically in ultra-sonic bath, and with hydrogen peroxid $\left(\mathrm{H}_{2} \mathrm{O}_{2}\right)$ (b)

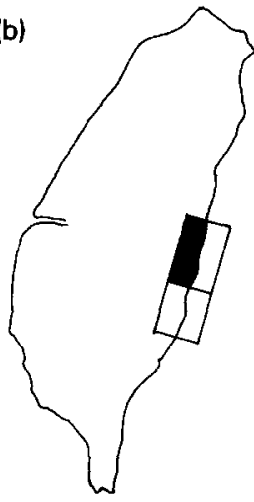

$8710 \pm 120 \approx 8760 \pm 110$

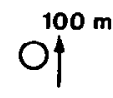

O

$\mathrm{O}$
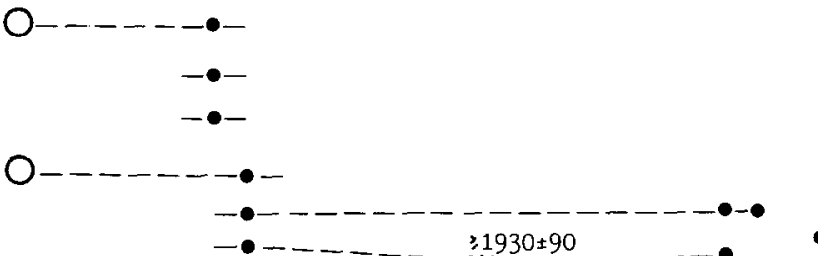

- $-2-\ldots ; 1930 \pm 90$
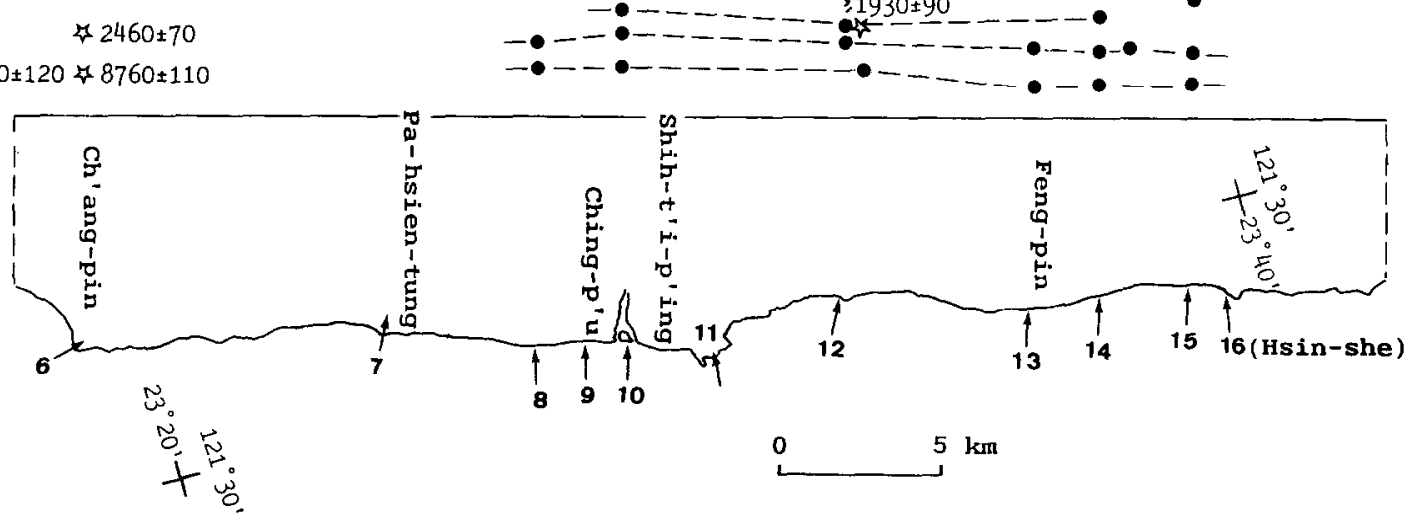

0 $5 \mathrm{~km}$

Fig. 2 (continued). 
before a leaching with dilute hydrocloric acid used to remove the portion of the matrix suspected to have been affected by exchange reactions.

For AMS, fragments of $30-80 \mathrm{mg}$ carbonate were isolated and first cleaned mechanically by shot blusting in order to remove surface contamination from infilling or detrital material. These fragments were then coarse-ground in a agate mortar and leached in $0.2-0.5 \mathrm{M}$ hydrocloric acid until more than $50 \%$ of the sample weight was removed.

All radiometric dates of Holocene shorelines available from the area considered, either new or compiled from the literature, have been summarized in Table 1. Intercepts of radiocarbon ages with the calibration curve by Stuiver et al. (1986) have been calculated using the computer programme proposed by Stuiver and Reimer (1986), employing for peat samples and driftwood the atmospheric calibration curve dataset and for marine samples the marine model with $\Delta R=140 \mathrm{yr}$. Average uplift rates have been obtained by dividing the paleoMSL elevations by the corresponding ${ }^{230} \mathrm{Th}$ ages or the calibrated ${ }^{14} \mathrm{C}$ ages.

In the absence of local relative sea-level curves, the estimation of former eustatic positions using ${ }^{18} \mathrm{O}$ data or calibrated dates from other areas can give first-order values only, due to the regional variability of the glacial-isostatic contribution (Nakada et al., 1991). Nevertheless, it has been assumed in this study that the regional eustatic sea level has been roughly similar to the present one during the last $6000 \mathrm{yr}$, near $-30 \pm 5 \mathrm{~m}$ around 9300 cal. yr BP, and near $-35 \pm 5 \mathrm{~m}$ around 9700 cal. yr BP (Shackleton, 1987; Bard et al., 1990).

\section{Sedimentological analyses}

Sand grain size was determined by sieving. The build-up of a clearly individualized sand population with a sigmoidal curve is a meaningful index of the action of a transport process.

The surface textures of the quartz grains were examined with a HITACHI S520 scanning electron microscope (SEM). The selected grains belong to previously determined depositional processes (high or low energy). Some analyses were performed using the energy-dispersive X-ray microanalysis system (Tracor NortherN) combined with SEM.

Madrepore crusts were observed in thin sections; somc particles were isolated by a dental drill, using X-ray diffractometry (Co radiation).

\section{Results}

Near Lung-nai Ch'iao (Fig. 2a, loc. 1), above a Plio-Pleistocene mudstone ledrock showing several holes made by borer shells, a coral head of Cyphastrea sp. was found in growth position at about $+4 \mathrm{~m}$ and dated $1010 \pm 70 \mathrm{yr}$ BP (Gif8641). In the same section, at $+5 \mathrm{~m}$, driftwood has been dated $950 \pm 40$ yr BP (NTU-1142) (Hsieh, 1990). This converging evidence indicates an average uplift rate between 4.8 and $5.5 \mathrm{~mm} / \mathrm{yr}$ in this area during the last thousand years. Similar or slightly lower rates can be obtained for the Ch'eng-kung area from other dates published in the literature (Table 1), with the exception of NTU-152 and -153 that suggest much faster rates, which, however, have not been confirmed by later work.

Between localities 3 and 4, a volcanic bedrock is locally distributed among mainly sedimentary rocks. Locality 3 is a tombolo near San-hsien-t'ai. Here, raised patch reefs culminating at $+17.5 \mathrm{~m}$ (Fig. 3) have developed above a volcanic basement. A coral sample of Platygyra sp., at $+15 \mathrm{~m}$, was dated $5080 \pm 70 \mathrm{yr}$ BP (Gif-8644) and one of Goniastrea sp., at $+14.5 \mathrm{~m}, 5010 \pm 100$ yr BP (Gif-8642), whereas a sample of Eptoria phrygia (Ellis and Solander) at $+8 \mathrm{~m}$ gave $2800 \pm 90 \mathrm{yr}$ BP (Gif-8645). This implies average uplift rates of at least $2.8 \mathrm{~mm} / \mathrm{yr}$. Local morphological indications of spasmodic crustal movements are absent.

Near Shih-yü-san (loc. 4), marks of several raised stepped shorelines are visible. The lowest one is marked at about $+5.5 \pm 6 \mathrm{~m}$ by a notch, clearly cut in a mudstone formation (Fig. 4) widening out occasionally into sea caves at the same level, and by intertidal marine incrustations (oysters, barnacles). An oyster shell collected in growth position has been dated $910 \pm 70 \mathrm{yr}$ BP (GifA-91090). At about $+10 \mathrm{~m}$ in the same sec- 


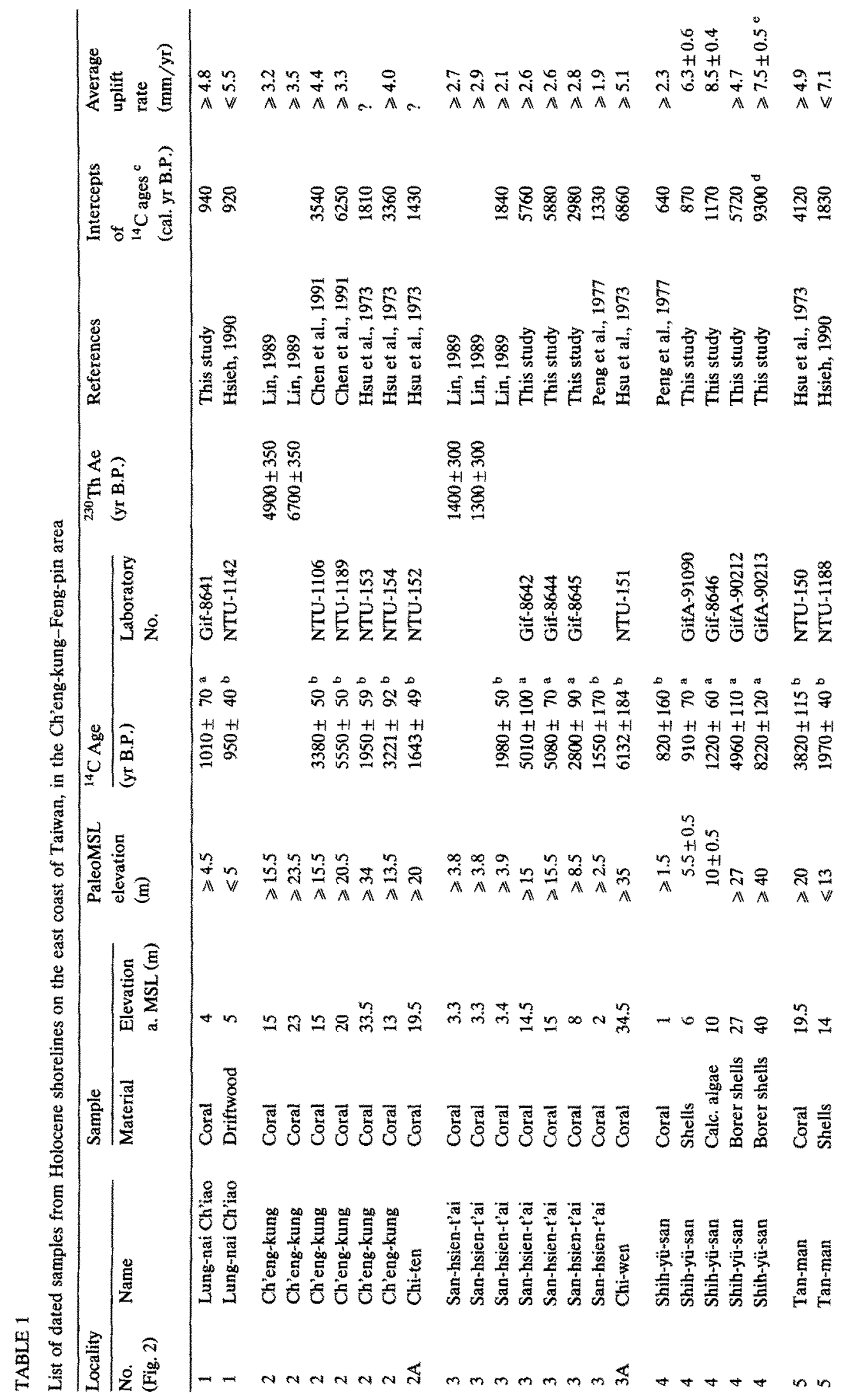




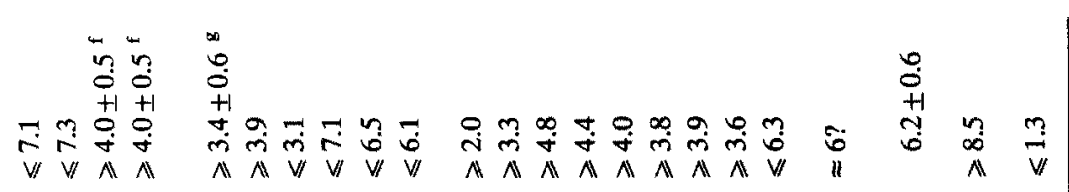

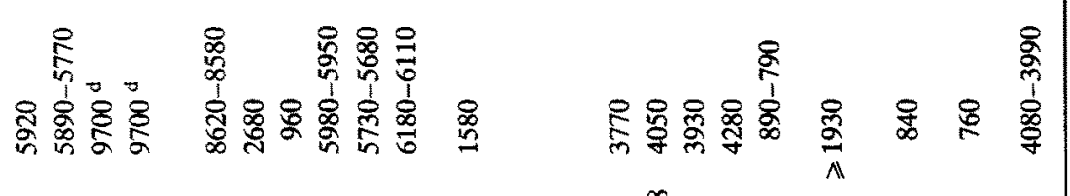

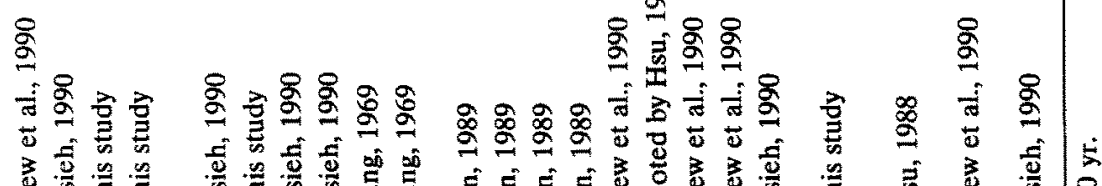

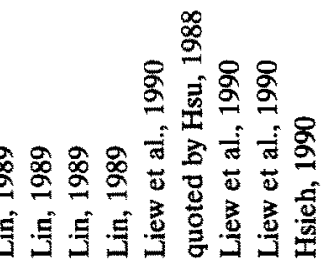

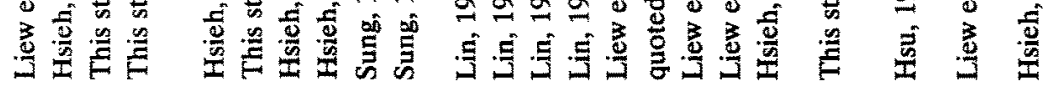

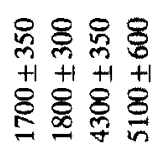

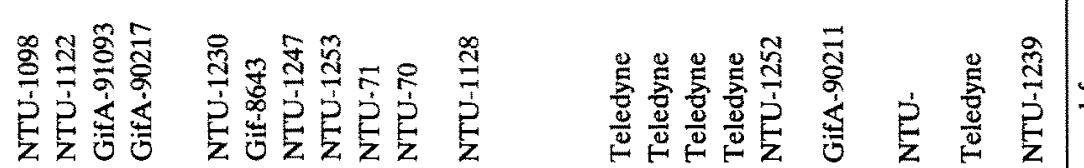

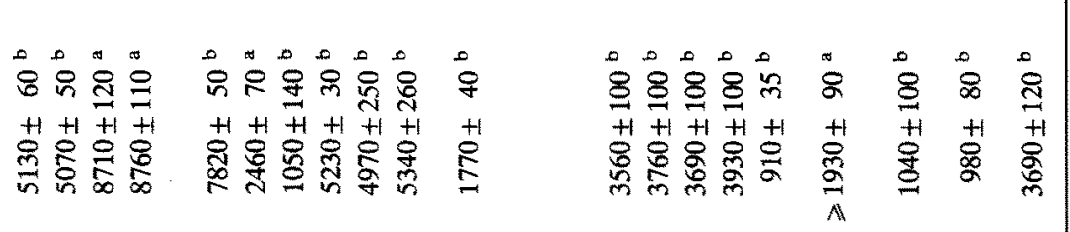

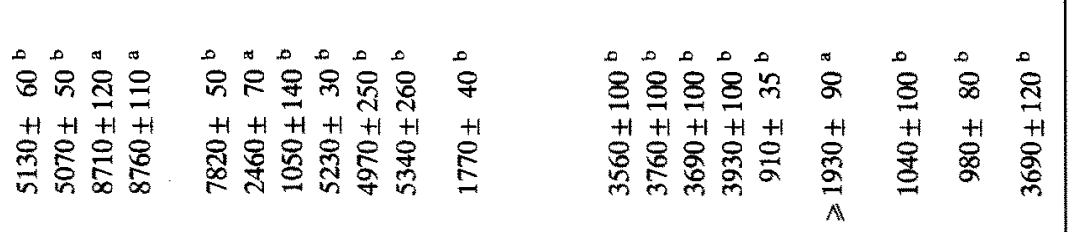

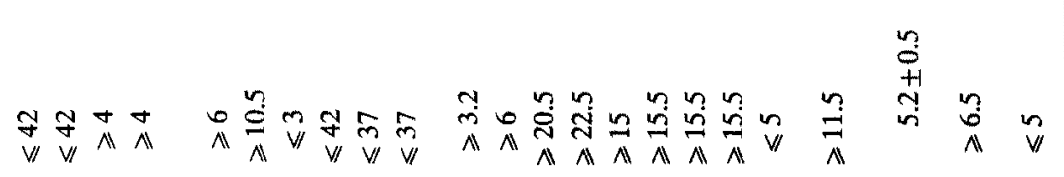
ㄱำ

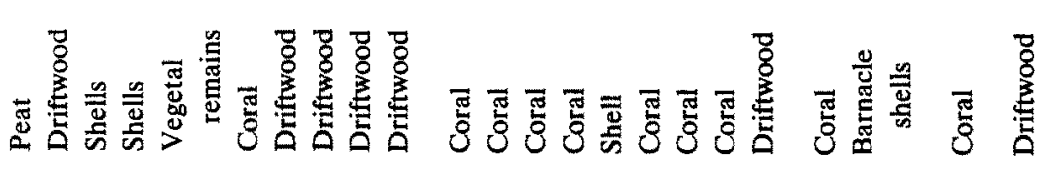

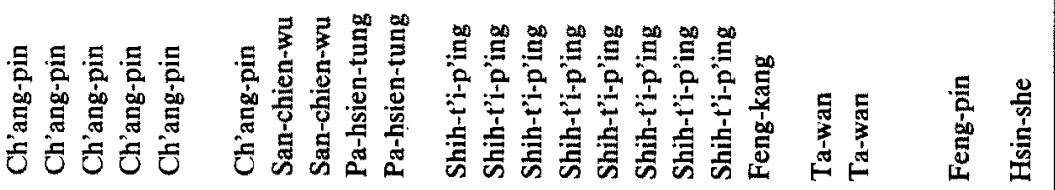

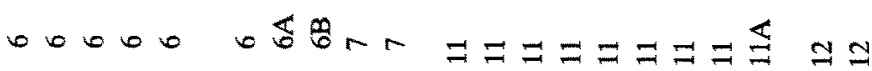

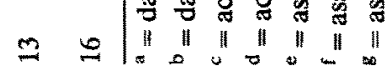




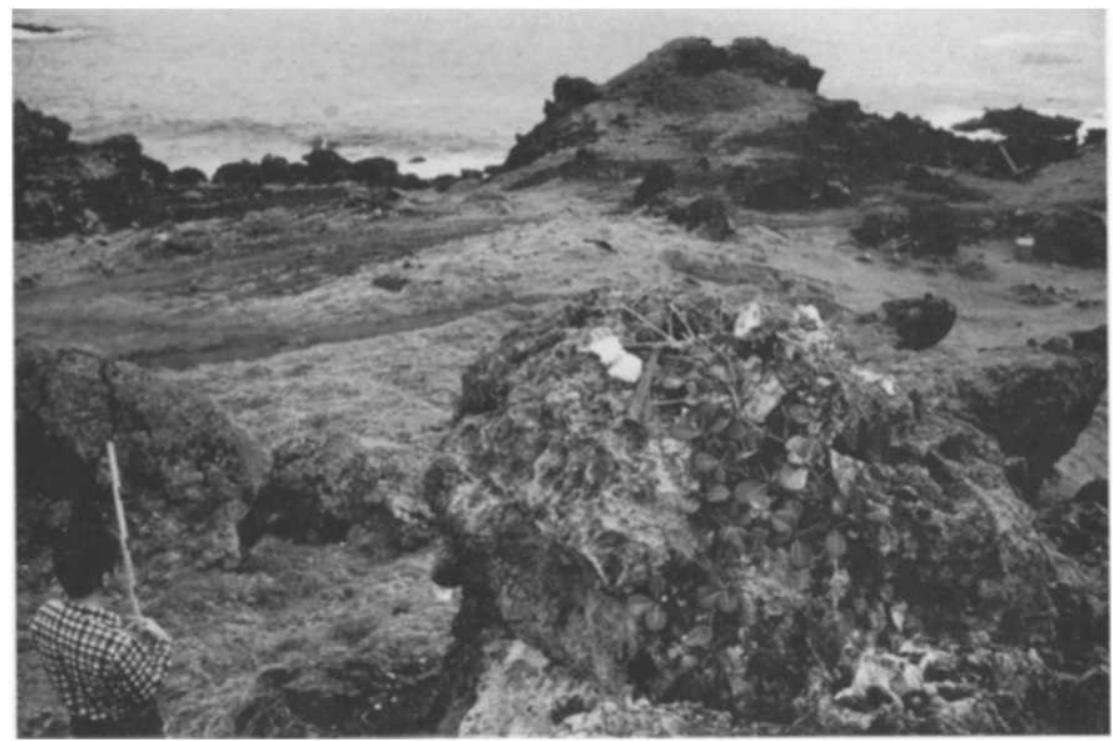

Fig. 3. Raised coral pinnacle reaching the altitude of $+17.5 \mathrm{~m}$ at Sanhsien-t'ai (loc. 3) (photo P.A. Pirazzoli).

tion, a second marine notch has developed behind a narrow bench, on the outer edge of which are remnants of a small algal ridge (Fig. 4). An algal sample from this formation has been dated $1220 \pm 60$ yr BP (Gif-8646).

Ncar the same place, a big limestone block showing marks of at least five superimposed shorelines projects from a coastal terrace slightly tilted towards the northeast. Notches cut into the abandoned cliffs of the block have been measured at about $3.5,6.5-7,8,9.5$, and $11-11.5 \mathrm{~m}$ above the land level, the elevation of which has been estimated at $+25 \pm 5 \mathrm{~m}$ (Fig. 5). Borer shells still in growth position have been collected from the base of the abandoned cliff at $1.7 \mathrm{~m}$ above the land level and dated by AMs $4960 \pm 110$ yr BP (GifA-90212). Similar borer shells were collected from another abandoned limestone cliff

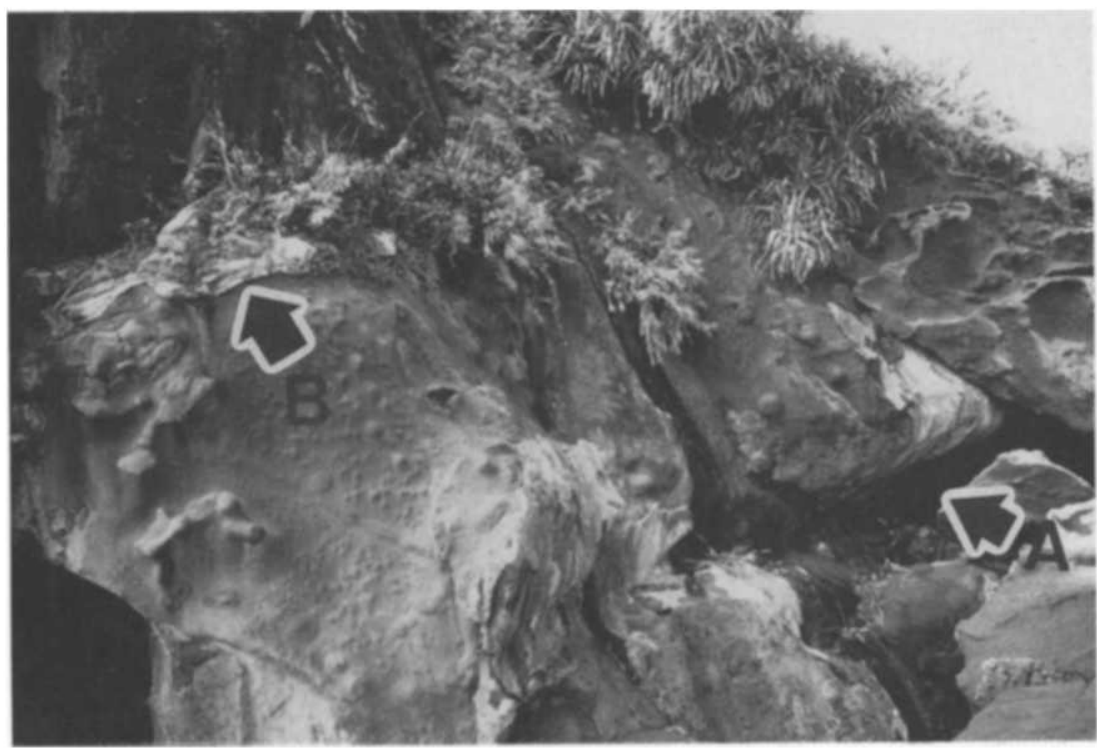

Fig. 4. The two lowest raised shorelines at Shih-yü-san (loc. 4). $A=$ notch at about $+5.5 \mathrm{~m}$, dated $910 \pm 70 \mathrm{yr}$ BP by in-situ oyster shells. $B=$ remnants of an algal ridge at about $+10 \mathrm{~m}$, dated $1220 \pm 60 \mathrm{yr}$ BP (photo P.A. Pirazzoli). 
$\mathbf{N}$

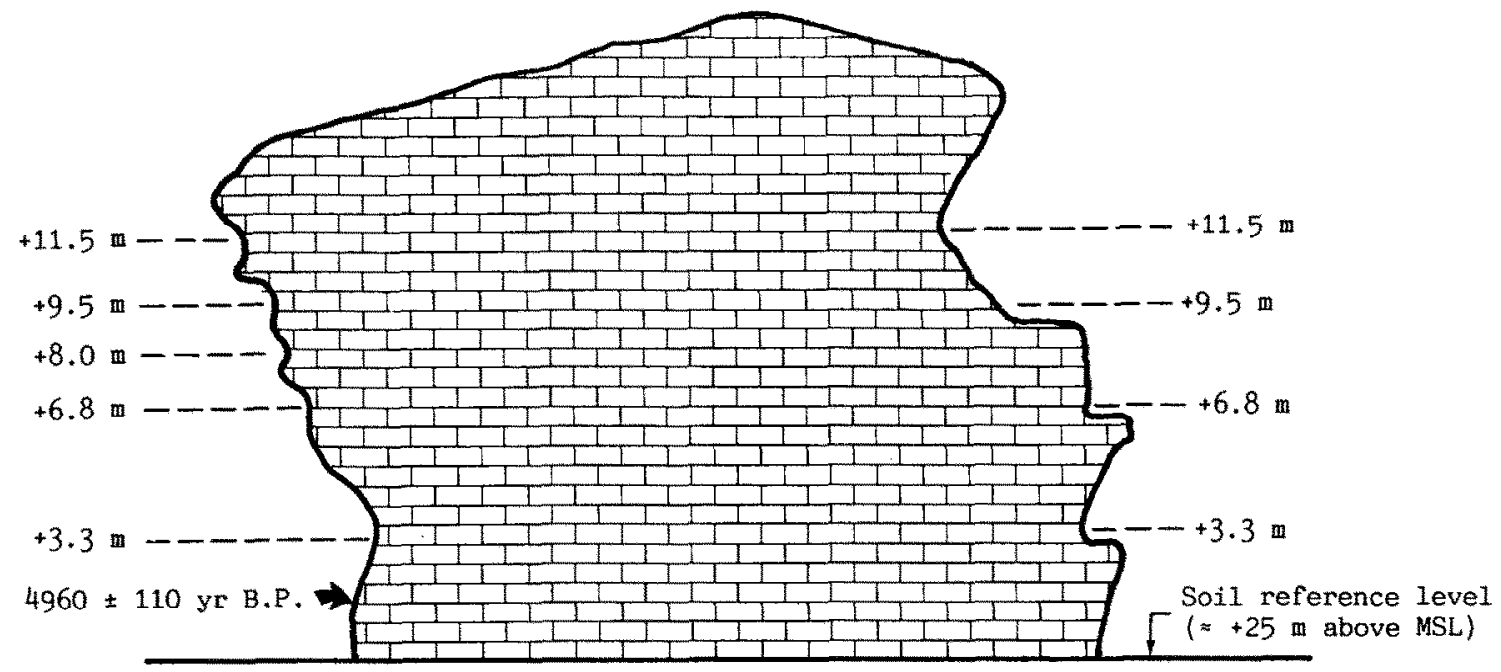

Fig. 5. Superimposed notches left by at least five Holocene sea levels are visible between about +25 and +37 m on a limestone rock near Shih-yü-san.

farther inland, at about $+40 \mathrm{~m}$, and dated 8220 \pm 120 yr BP (GifA-90213). Average uplift rates between 5 and $8.5 \mathrm{~mm} / \mathrm{yr}$ can be deduced for this area. The tectonic behaviour seems faster therefore near Shih-yü-san than near San-hsient'ai.

Two streams run near localities 3 and 4 . The stream just north of locality 4 tends to migrate southwards, whereas the stream just north of locality 3 tends to migrate northwards. This suggests that a difference in uplift rates exists between these two localities. The elevation of the highest Holocene surface varies from $+60 \mathrm{~m}$ in the north to $+40 \mathrm{~m}$ near locality 3 before increasing again to $+50 /+60 \mathrm{~m}$ in the south. The new radiocarbon ages obtained in this area support the idea that a differential uplift is occurring here, with a higher rate in locality 4 and a lower one in locality 3 . This coastal zone is located near the area where the extension of the Luzon arc reaches the Eurasian continental margin (Fig. 1). Local warping and faulting are probably a reflection of the intensive compression taking place here.

At Tan-man (loc. 5), upper beach deposits at $+14 \mathrm{~m}$, dated $1970 \pm 40$ yr BP, give an estimation of maximum uplift rate.

Near Ch'eng-shan (north of loc. 5), a 2-3 m thick sand layer at about $+56 \mathrm{~m}$, just below the top of the uppermost Holocene surface, was interpreted, at first sight, as possibly marine. However, detailed sedimentological and mineralogical analyses only revealed poorly sorted fluvial azoic sands, whereas exoscopic analysis showed quartz and pyroxene grains without any wear traces. The grains exhibit an advanced solution typical of soil formation evolution; furthermore, edges were not eroded by an aqueous activity. Some of these grains are characterized by an important coating of amorphous silica (Fig. 6), precluding any possible influence of a marine environment when this layer was deposited. Other samples in nearby sections, however, include deposits which can be considered as of marine origin, owing to (1) their good sorting, (2) the presence of metamorphic materials that can only have been brought there by the Hsiu-ku-luan River (loc. 10) and presently are found on the beach between localities 10 and 5 , and (3) sedimentary structures (various kinds of cross-bedding indicating paleocurrent directions perpendicular to the shore) characteristic of shoreface deposits.

Near Shin-men Ch'iao $(1.5 \mathrm{~km}$ NNE of Ch'eng-shan), a sand layer $16 \mathrm{~m}$ below the terrace surface, though devoid of marine fauna remains, could have passed through a transitory marine phase as shown by grain-size evidence concerning its granulometric characteristics and 

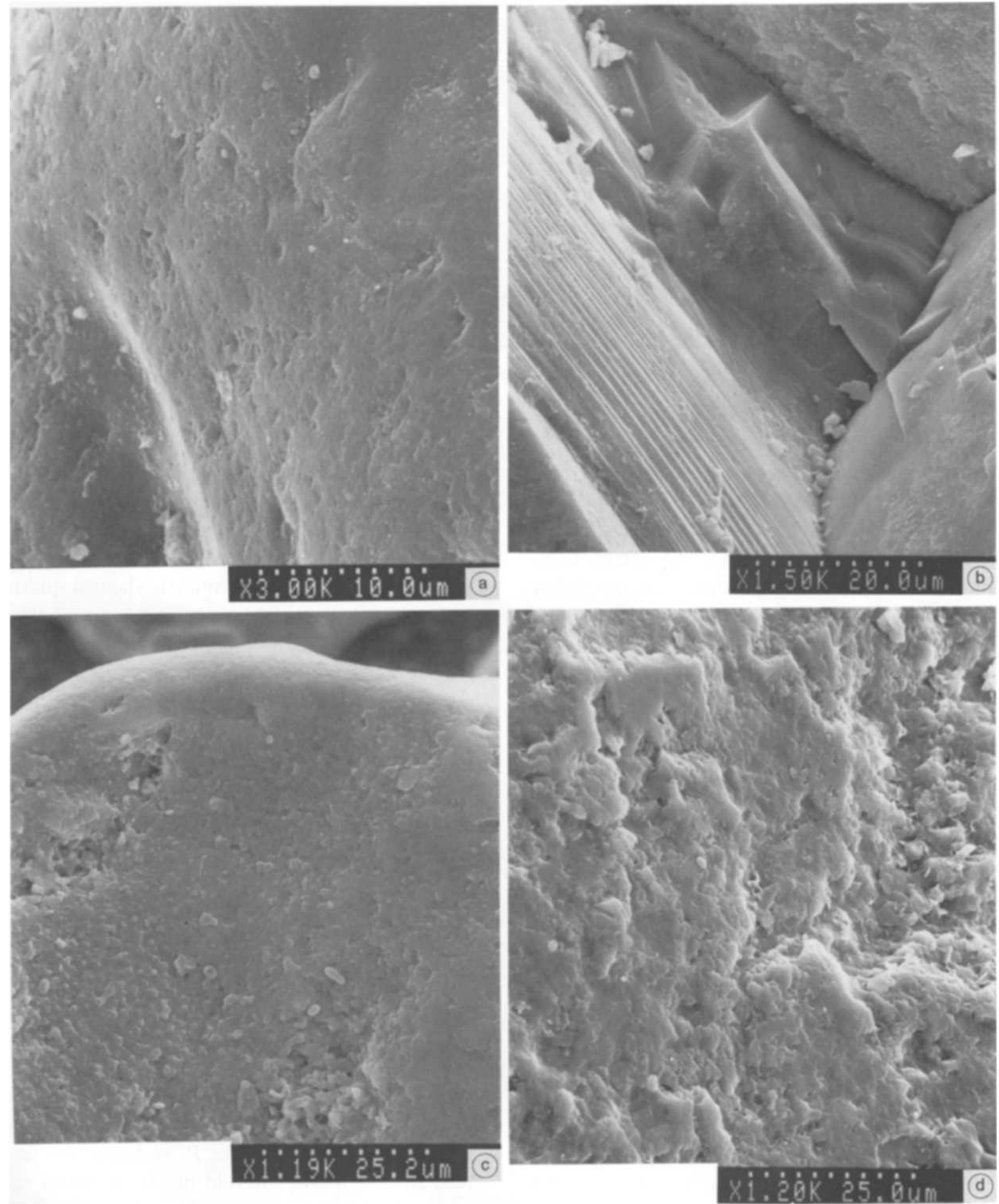

Fig. 6. SEM examination of quartz grains from the Ch'eng-shan area. (a) Small shock marks, $v$ 's polishing related to a short river transportation. (b) Advanced solution of siliceous material, edges were preserved from any erosion. (c) Grain largely coated with various deposits. (d) Detail of siliceous coating with flowing casts (photos P. Giresse), 
mineralogic composition. Four metres lower in the same section, however, a sandy silt layer shows a more alluvial origin, characterized by grain-size features; a poor sorting and especially the fine and coarse ends of the curves evidenced by the skewness and kurtosis indexes, demonstrate that neither the fine grains were winnowed nor the coarse ones strongly selected by a powerful and long-lasting action.

Near Ch'ang-pin (loc. 6), a heterogenic deposit containing worn fragments of marine shells forms a cliff near the present-day beach. A sample of Anomia chinensis shells collected from the cliff was dated by AMs to be $8710 \pm 120$ yr BP (GifA91093), and one of Gafrarium humidum shells, $8760 \pm 110$ yr BP (GifA-90217). These two samples are interpreted, together with sample NTU1230 , as offshore submarine slumping deposits, or as nearshore deposits, mixed with alluvial or colluvial sediments, left about 9700 yr ago (calibrated age; Bard et al., 1992), when sea level was possibly near $-35 \pm 5 \mathrm{~m}$ (Shackleton, 1987; Bard et al., 1990) and was rising at a rate of $9 \mathrm{~mm} / \mathrm{yr}$ (Bard et al., 1990). A local average uplift rate greater than $4.0 \pm 0.5 \mathrm{~mm} / \mathrm{yr}$ can be deduced from the above data. A similar value of at least $3.9 \mathrm{~mm} / \mathrm{yr}$ has been obtained in the same area from a coral specimen dated $2460 \pm 70 \mathrm{yr}$ BP
(Gif-8643), sampled at $+10 \mathrm{~m}$ above a basal conglomerate capping an erosional surface.

Because no dates of marine samples are available between localities 6 and 11, only maximum uplift rates could be estimated. At Pa-hsien-tung (loc. 7), wide sea caves (now used as Buddhist shrines) can be seen at five main levels (floor altitudes at about $+21,+38,+59,+72$, and $+100 \mathrm{~m}$; other sea caves are reported at higher elevations). Their impressive size suggests that the sea took a long time to excavate each of these caves. If the two lower levels were excavated, or more likely reworked and deepened, during the Holocene, the development of most of the sea caves must be older. This raises the question of the duration of the uplift trends that are observed along the coast. The fact that certain sea caves possibly formed during the Pleistocene were again reached by the sea during the Holocene, may mean that they were formed during Pleistocene low-stands of sea level and/or that strong uplift trends now prevailing along the east coast of Taiwan could have been interrupted in the Pleistocene (if the sea caves are Pleistocene in age) by periods of reversed vertical tectonic movements.

Near Ching-p'u (loc. 9), at least five raised erosion levels cut into the andesitic breccias can be observed along the coast between the beach

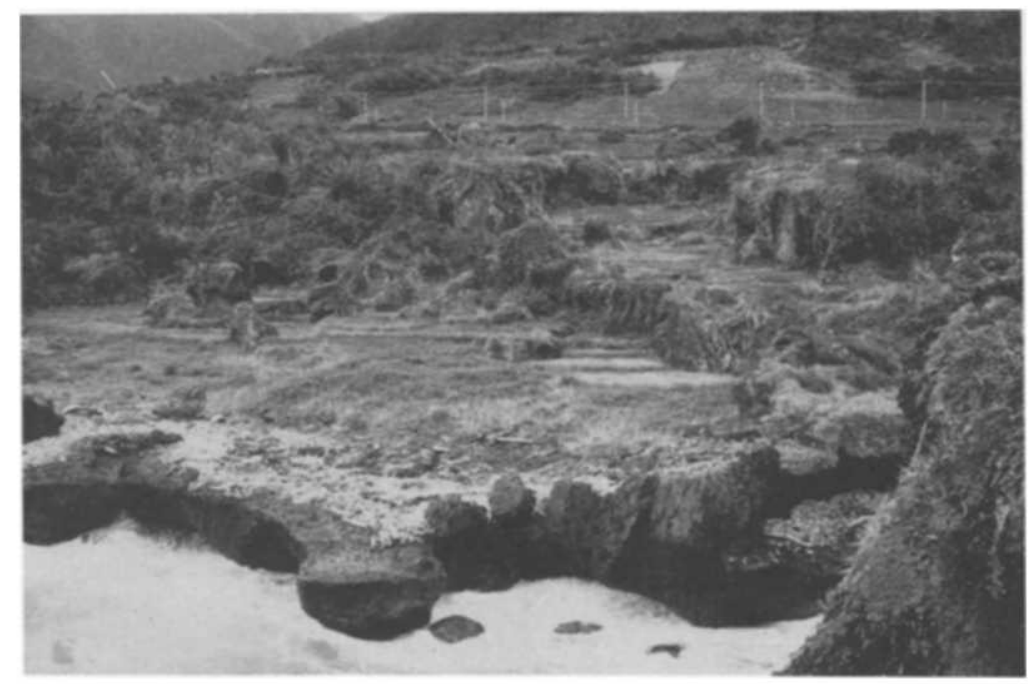

Fig. 7. Several stepped shorelines (abrasion benches, abandoned cliffs, sea caves), cut by marine erosion into an andesitic breccia, are easily recognizable among the vegetation north of locality 10 (photo P.A. Pirazzoli). 
and the road (Fig. 7), and at least another three levels at about $+28,+32$, and $+38 \mathrm{~m}$, respectively. The occurrence of these several-stepped shorelines suggests that the uplift trend took place in sudden jerks, interspersed by periods of relativcly stablc sea lcvel, rather than gradually. At Shih-t'i-p'ing (loc. 11), the lowest step has been dated about $1800 \mathrm{yr} \mathrm{BP}$, and coral formations from +15 to $+22 \mathrm{~m}$ between 3600 and $5100 \mathrm{yr}$ BP. This gives average uplift rates of the order of 4-5 mm/yr.

North of Shih-t'i-p'ing, the bedrock is volcanic or volcaniclastic and no significant marine sediments are preserved; this is especially true of biogenic incrustations, which are easily eroded. Former shorelines are recognized from erosional features (notches, benches, sea caves) or, at the lower level, from intertidal marine incrustations. Only a few marine deposits, all younger than 2000 yr BP, could be dated here, using barnacles and in-situ corals. Four to five steps are recognizable on certain transects and the highest Holocene shoreline still preserved is at about $+20 \mathrm{~m}$. The only new date provided here has been obtained with AMs from very small fragments of a madrepore crust collected from the walls of a raised sea cave. The madrepore crust shows a regressive diagenetic sequence, with two generations of secondary vadose cements (calcitic micrite and microsparitic cements) of meteoric origin, forming a veneer partially capping the aragonitic madrepore walls, still not recrystallized (Fig. 8). The pretreatment of the sample may have been inappropriate to remove all possible contamination sources. The date obtained $(1930 \pm 90$ yr BP: GifA-90211) is therefore a minimum age. Nevertheless, the average uplift rate deduced from this sample $(\approx 6 \mathrm{~mm} / \mathrm{yr})$ is of the same order as the average rates which can be deduced from other dates in the same area.

\section{Discussion}

In a previous paper, Liew et al. (1990) distinguished three major Holocene surfaces in the study area, containing at least five distinct terraces. Their number would probably be much greater if all marine marks would have been preserved. The uppermost surface, recognized from geomorphological characteristics, was reported at an elevation of 65-70 m (inner edge) north of Ch'eng-kung, at about $50 \mathrm{~m}$ near

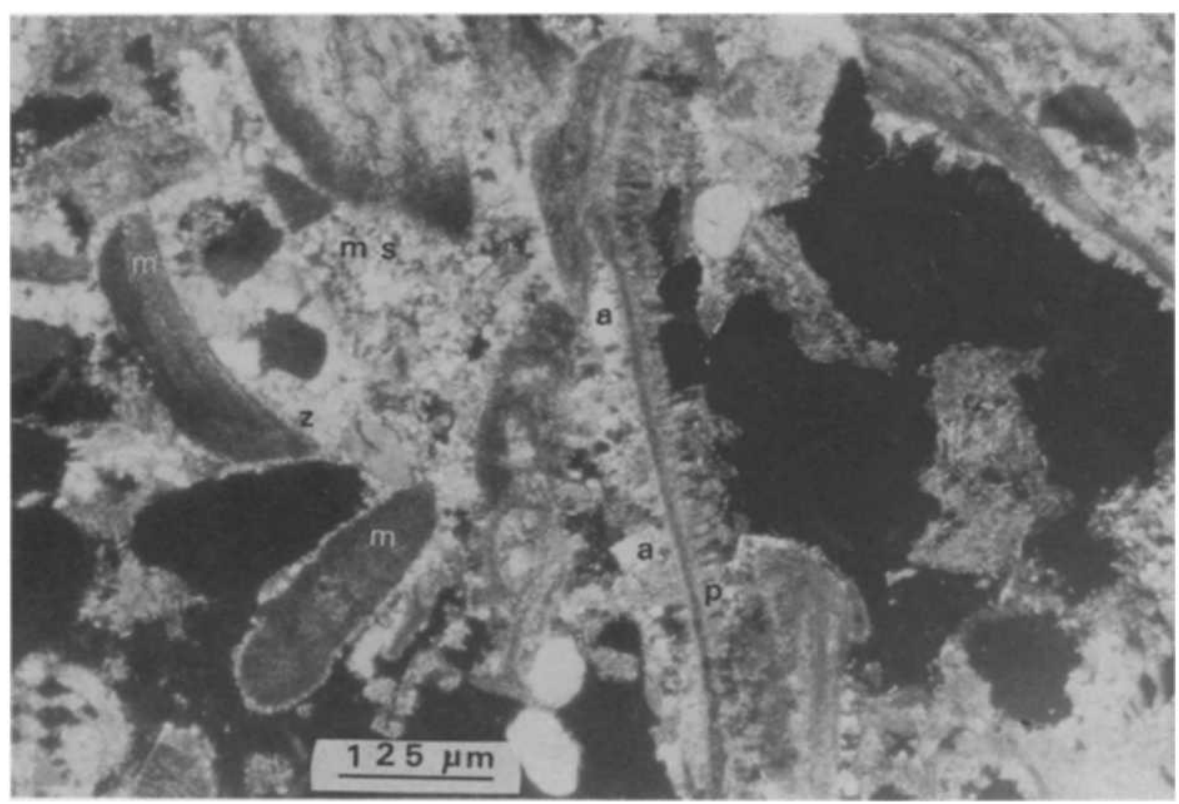

Fig. 8. Secondary fillings in aragonitic gastropores from Madreporaria. $a=$ aragonitic walls; $p=$ drusy calcite in epitaxial growth; $m=$ micritic calcite fillings; $m s=$ microsparitic fillings (photo $P$. Giresse). 
Ch'ang-pin, at $37-38 \mathrm{~m}$ between Pa-hsien-tung and Shih-t'i-p'ing, and at $26 \mathrm{~m}$ near Feng-pin.

South of Ch'ang-pin (loc. 6), sedimentary bedrock prevails and large alluvial fan deltas have developed locally. In this part of the coast, Holocene terraces are found at the highest altitudes, though demonstration of a clear marine influence at the highest levels is often a hard task. The upper boundary between marine and alluvial deposits is difficult to distinguish, various kinds of terrestrial and marine layers appearing frequently interfingered in most sections (Hsieh, 1990). Near Ch'eng-kung, just above the abraded mudstone basement of the terraces, corals in growth position can be found in certain sections, whereas sand layers in other sections are certainly not marine according to our sedimentological analyses.

The preceding examples from Ch'eng-shan show that it is very difficult to demonstrate the marine origin of several coastal surfaces: steep slopes of poorly consolidated rock, heavy rainfall, recurrent great earthquakes and strong uplift and erosion rates must have caused frequent landslides in the coastal and nearshore zones of the eastern Coastal Range, bringing intermittently huge masses of land sediments to the narrow coastal zone which may have been deposited nearshore and even offshore before having acquired typical marine or coastal characteristics.

The main NE-trending thrusts along the coast usually separate volcanic and sedimentary rocks, resulting in a coastal zone of alternating bedrock. Sharp differences in elevation between marine terraces on both sides of a fault could not be detected in the field, due to the unequal development and preservation conditions of the terraces. The southward increasing elevation of the terraces, already pointed out by Liew et al. (1990), can be confirmed: the remaining Holocene surfaces are found higher and with more steps towards the south in the area investigated, although only one part of the raised shorelines could be dated. It is not impossible, however, that higher terraces have been completely eroded in other coastal sectors, e.g., on the northernmost sector of the study area.

\section{Conclusions}

The present work has confirmed that there was a rapid uplift of the coastal area between Ch'eng-kung and Hsin-she during the Holocene, at avcrage rates of the order of a few to scveral millimetres per year depending on the sector considered. Though the uppermost marine limits are generally poorly preserved, and therefore difficult to identify in most terraces, in-situ borer shells as high as $40 \mathrm{~m}$ have been dated $8200 \mathrm{yr} \mathrm{BP}$ and fossil beach deposits of $8750 \mathrm{yr}$ BP have also been found emerged.

At least five superimposed shorelines developed near locality 4 between +25 and $+37 \mathrm{~m}$ during the period $8000-5000$ yr BP. As the eustatic sea level was probably rising until about $6000 \mathrm{yr} \mathrm{BP}$, each shoreline could be formed only during time intervals when the rate of land uplift and that of sea level rise were similar. However, some uplift movements must have occurred in steps, especially near location 4 , with coseismic vertical displacements of the order of a few metres; they were rapid enough to displace the shoreline downwards, from one notch to the level of the next one, and to preserve borer shells from strong intertidal bioerosion; they remained in situ but otherwise would have been destroyed very rapidly (in at most a few years).

Near Ching-p'u, where eight superimposed erosional steps are preserved between +5 and $+38 \mathrm{~m}$, at least the five lower steps, which have developed since $5000 \mathrm{yr} \mathrm{BP}$, correspond to very rapid shoreline displacements with a recurrence period of about $1000 \mathrm{yr}$. As the youngest level was raised around $1000 \mathrm{yr} \mathrm{BP}$, a new very fast vertical displacement may be imminent here.

\section{Acknowledgements}

This is a contribution to the IGCP Project 274 "Coastal evolution in the Quaternary" and to the activities of the task group "Palaeoseismicity of the Late Holocene" of the Inter-Union Commission on the Lithosphere, and of the INQUA Commissions on Neotectonics and on Quaternary Shorelines. The participation of P.A.P. to the 
field work has been made possible by Professor J. Angelier, in the framework of the Cooperation programme in Earth Sciences between France and Taiwan. We thank Professor Dai for identification of coral samples, Y. Mart, $O$. van de Plassche and an anonymous referee for constructive suggestions, and Ms M. Delahaye for revising the English.

\section{References}

Angelier, J. (Editor), 1990. Geodynamic Evolution of the Eastern Eurasian Margin. Tectonophysics, 183(1/4): 1362.

Angelier, J., Blanchet, R., Ho, C.S. and Le Pichon, X. (Editors), 1986. Geodynamics of the Eurasia-Philippine Sea Plate Boundary. Tectonophysics, 125(1/3): 1-287.

Arnold, M., Bard, E., Maurice, P. and Duplessy, J.C., 1987. Status report on ${ }^{14} \mathrm{C}$ dating at the Gif-sur-Yvette Tandetron. Nucl. Instrum. Methods, 29: 120-123.

Arnold, M., Bard, E., Maurice, H., Valladas, H. and Duplessy, J.C., $1989 .{ }^{14} \mathrm{C}$ dating with the Gif-sur-Yvette Tandetron accelerator: status report and study of isotopic fractionations in the sputter ion source. Radiocarbon, 31(3): 284-291.

Bard, E., Hamelin, B. and Fairbanks, R.G., 1990. U-Th ages obtained by mass spectrometry in corals from Barbados: sea level during the past 130,000 years. Nature, 346: $456-$ 458.

Bard, E., Arnold, M., Fairbanks, R.G. and Hamelin, B., 1993. 230 Th-234U and $14 \mathrm{C}$ ages obtained by mass spectrometry on corals. Radiocarbon, 35(1): 191-199.

Chen, W.S., Huang, M.T. and Liu, K.T., 1991. Neotectonic significance of the Chimei Fault in the Coastal Range, eastern Taiwan. Proc. Geol. Soc. China, 34(1): 43-56.

Chi, W., Namson, J. and Suppe, J., 1985. Stratigraphic record of plate interactions in the Coastal Range of eastern Taiwan. Mem. Geol. Soc. China, 4: 155-194.

Hsieh, M.L., 1990. The Study of Late Quaternary Deposits, Marine Terraces and Neotectonism of the Coastal Area between Hualien and Taitung. M.S. Thesis, Nat. Taiwan Univ., Taipei (in Chinese, unpubl.).

Hsu, Yu.C., Chou, M.C., Hsu, Yi.C., Lin, S.Y. and Lu, S.C., 1973. National Taiwan University radiocarbon measurements, II. Radiocarbon, 15: 345-349.

Hsu, M.Y., 1988. A Gcomorphological Study of Marinc Tcrraces in Taiwan. Ph.D. Thesis, Inst. Earth Sci., Chinese Culture Univ., Taipei (in Chinese, unpubl.).

Huang, C.Y. and Lin, S.B., 1991. The geologic role of the Huatung Ridge, offshore eastern Taiwan. Annu. meet. Geol. Soc. China, Taipei, R.O.C., Progr. Abstr., p. 72.

Lai, C.K., 1986. The Study of Marine Terraces from Chengkung to Fenping, Coastal Range, eastern Taiwan. M.S. Thesis, Nat. Taiwan Univ., Taipei, 101 pp. (in Chinese).
Lee, T.Q., 1989. Evolution technique et géodynamique néogène et quaternaire de la Chaîne côtière de Taiwan: apport du paléomagnétisme. Thèse Doct., Univ. Paris VI, $328 \mathrm{pp}$.

Liew, P.M., Hsieh, M.L. and Lai, C.K., 1990. Tectonic significance of Holocene marine terraces in the Coastal Range, eastern Taiwan. In: J. Angelier (Editor), Gcodynamic Evolution of the Eastern Eurasian Margin. Tectonophysics, 183: 121-127.

Lin C.C., 1969. Holocene geology of Taiwan. Acta Geol. Taiwan., 13: 83-126.

Lin, J.F., 1989. Studies of ${ }^{234} \mathrm{U} /{ }^{230} \mathrm{Th}$ Dating on the Holocene Corals of Eastern and Southern Taiwan. M.S. Thesis, Nat. Taiwan Univ., Taipei (in Chinese).

Liu, C.C. and Yu, S.B., 1990. Vertical crustal movements in eastern Taiwan and their tectonic implications. In: J. Angelier (Editor), Geodynamic Evolution of the Eastern Eurasian Margin. Tectonophysics, 183: 111-119.

Nakada, M., Yonekura, N. and Lambeck, K., 1991. Late Pleistocene and Holocene sea-level changes in Japan: implications for tectonic histories and mantle rheology. Palaeogeogr. Palaeoclimatol. Palaeoecol., 85: 107-122.

Peng, Z., Li, Y, and Wu, F., 1977. Tectonic uplift of Taiwan island since the early Holocene. Mem. Geol. Soc. China, 2: 57-69.

Pirazzoli, P.A., 1978. High stands of Holocene sea levels in the northwest Pacific. Quat. Res., 10: 1-29.

Shackleton, N.J., 1987. Oxygen isotopes, ice volume and sea level. Quat. Sci. Rev., 6: 183-190.

Shih, T., Teng, K., Hsu, M. and Yang, G., 1988. A geomorphological study of marine terraces on Huatung coast of Taiwan. Geogr. Res. Inst., Nat. Taiwan Normal Univ., 14: $1-50$.

Stiros, S.C., Arnold, M., Pirazzoli, P.A., Laborel, J., Laborel, F. and Papageorgiou, S., 1992. Historical coseismic uplift on Euboea Island, Greece. Earth Planet. Sci. Lett., 108: 109-117.

Stuiver, M. and Reimer, P.J., 1986. A computer program for radiocarbon age calibration. Radiocarbon, 28(2B): 10221030.

Stuiver, M., Pearson, G.W. and Braziunas, T., 1986. Radiocarbon age calibration of marine samples back to $9000 \mathrm{cal} \mathrm{yr}$ BP. Radiocarbon, 28(2B): 980-1021.

Sung, W.H., 1969. Changping culture, the first pre-ceramic culture of Taiwan. Newsl. Chin. Ethnol, 9: 1-27 (in Chinese).

Van de Plassche, O. (Editor), 1986. Sea-Level Research: A Manual for the Collection and Evaluation of Data. Geo Books, Norwich, 618 pp.

Yang, K.M., Wang, Y., Tsai, Y.B. and Hsu, V., 1983. Paleomagnetic studies of the Coastal Range, Lutao and Lan Hsu in eastern Taiwan. Bull. Inst. Earth Sci., Acad. Sin., 3: 173-190.

Yang, T.Y., Liu, T.K. and Chen, C.H., 1992. Fission track of Lutao volcanics: implications of partial annealing and eruption history. J. Geol. Soc. China, 35: 19-42. 